\section{Effects of Real-time Location-specific Drip Irrigation Scheduling on Water Use, Plant Growth, Nutrient Accumulation, and Yield of Florida Fresh-market Tomato}

Ibukun T. Ayankojo ${ }^{1}$, Kelly T. Morgan, and Monica Ozores-Hampton Institute of Food and Agricultural Science, South West Florida Research and Education Center, University of Florida, Immokalee, FL 34142

Kati W. Migliaccio

Department of Agricultural and Biological Engineering, University of Florida, Gainesville, FL 32611

Additional index words. Solanum lycopersicum, SmartIrrigation, best management practices (BMP), irrigation App, nutrient management

\begin{abstract}
Florida is the largest fresh-market tomato (Solanum lycopersicum L.)producing state in the United States. Although vegetable production requires frequent water supply throughout the crop production cycle to produce maximum yield and ensure high-quality produce, overirrigation can reduce crop yield and increase negative environmental consequences. This study was conducted to evaluate and compare irrigation schedules by a real-time and location-specific evapotranspiration (ET)-based SmartIrrigation Vegetable App (SI) with a historic ET-based schedule (HI). A field study was conducted on drip-irrigated, fresh-market tomato during the Fall of 2015 and Spring of 2016 on a Florida sandy soil. The two scheduling methods (SI and HI) were evaluated for irrigation water application, plant biomass accumulation, nutrient uptake and partitioning, and yield in open-field tomato production. Treatments included $100 \% \mathrm{HI}$ (T1); 66\% SI (T2); 100\% SI (T3); and 150\% SI (T4). Treatments were arranged in a randomized complete block design with four replicates per treatment during the two production seasons. In both seasons, depth of irrigation water applied increased in the order of $\mathbf{T} 2<\mathbf{T} 3<\mathbf{T} 1<\mathbf{T} 4$. Total water savings was greater for $\mathbf{T} 3$ schedule compared with $\mathrm{T} 1$ schedule at $22 \%$ and $16 \%$ for fall and spring seasons, respectively. No differences were observed among treatments for tomato biomass accumulation at all sampling periods during both seasons. However, T3 resulted in significantly greater total marketable yield compared with other treatments in both seasons. The impact of irrigation application rate was greater in fruit and leaf nitrogen accumulation compared with that of stem and root biomass. Based on the plant performance and water savings, this study concludes that under a sandy soil condition, a real-time location-specific irrigation scheduler improves irrigation scheduling accuracy in relation to actual crop water requirement in open-field tomato production.
\end{abstract}

Tomato production in the United States is dominated by the states of California and Florida (Costa and Heuvelink, 2005). In Florida, tomato total harvested area was 11.34 thousand ha with the production value of US\$382 million in 2016 (USDA, 2017). In 2015 , Florida fresh-market tomato was $36 \%$ of the total production value in the United States (FDACS, 2017). In 2015, tomato ranked fourth in value among all agricultural commodities (crops) in Florida, with orange,

Received for publication 30 Apr. 2018. Accepted for publication 25 June 2018 .

We acknowledge the U.S. Department of Agriculture (USDA) through the National Institute of Food and Agriculture (NIFA) for their financial support for this research.

${ }^{1}$ Corresponding author. E-mail: iayankojo@ufl. edu. contaminations (Zegbe et al., 2006; ZegbeDominguez et al., 2003, Zotarelli et al., 2009a). Excessive irrigation increases percolation, reducing water use efficiency and nutrient retention in sandy soils (Zotarelli et al., 2009b).
Irrigation scheduling methods are established procedures to determine the adequate irrigation volume and timing for a specific crop stage (Morgan et al., 2010) and can have a significant impact on the water and nutrient uptake and use efficiencies in tomato production (Zotarelli et al., 2009a). Therefore, proper irrigation scheduling could contribute to increase in crop yield as well as improve the economic viability of crop production.

There are several irrigation scheduling methods used in vegetable production in Florida, such as time-based scheduling (Migliaccio et al., 2008), schedule based on soil moisture (Zotarelli et al., 2009b), and ET scheduling based on weather information (Migliaccio et al., 2016; Morgan et al., 2006). Time-based scheduling results in lower water and energy use efficiencies compared with soil moisture- and ET-based scheduling because soil moisture conditions and real-time weather data are not considered in this schedule (Dukes, 2012; Kisekka et al., 2010; Migliaccio et al., 2008). One of the commonly adopted ET-based irrigation schedules is the use of long-term historical ET (historic ET-based schedule) by averaging weather data for a specific time period and area or location (Davis and Dukes, 2010). Because this scheduling method does not use real-time weather data, scheduling may not accurately represent the actual water requirement of a particular crop in a specific season and location.

SI is one of the most recent ET-based irrigation decision support systems that uses real-time weather data to estimate irrigation schedules for several crops grown in Florida (Migliaccio et al., 2014). SI Apps are ET-based models designed as smartphone applications using reference evapotranspiration (ETo) from FAO Penman-Monteith (Allen et al., 1998) procedure and crop coefficient $(\mathrm{Kc})$ to determine crop water requirement (Migliaccio et al., 2016). In addition, SI Apps (SI App for several crops in Florida and Georgia are available for download at http://smartirrigationapps.org/) have the ability to reduce user calculation error or misplaced irrigation records and timing. The smartphone irrigation apps are not only effective in reducing crop irrigation volume but also can significantly increase crop yield (Vellidis et al., 2014).

Although the effects of irrigation amount, frequency, and scheduling methods on tomato have been extensively studied, none of these focused on determining the effects of real-time, site-specific irrigation on productivity (Kirda et al., 2004; Patanè and Cosentino, 2010; Zegbe-Dominguez et al., 2003; Zotarelli et al., 2009a). In recent years, there has been an increasing trend of more studies focusing on improved tomato water use without compromising yield and fruit quality (Nangare et al., 2016; Patanè et al., 2011; Topcu et al., 2007). Therefore, the objective of this study was to compare the efficacy of an ET-based, real-time, and location-specific irrigation scheduling to irrigation schedules base on historic ET information in open-field, fresh-market tomato 
production. Tomato plant biomass accumulation, nutrient uptake and accumulation, and yield were used to determine the efficacy of the two ET-based irrigation scheduling methods. This study hypothesized that based on crop performance and irrigation water savings, irrigation based on location-specific and real-time weather information improves irrigation scheduling accuracy in relation to actual crop water requirement in tomato crop compared with a schedule that is based on historical weather data.

\section{Materials and Methods}

Experimental site and treatments applications. Two trials were conducted on dripirrigated open-field, fresh-market tomato in Fall 2015 and Spring 2016 (planting and final harvest dates: 14 Sept. and 23 Dec. 2015, for the fall season; 3 Feb. and 31 May 2016 for spring season). Both experiments were conducted at the University of Florida, Southwest Florida Research and Education Center in Immokalee, FL $\left(26^{\circ} 27^{\prime} 44^{\prime \prime} \mathrm{N}\right.$ and longitude $81^{\circ} 26^{\prime} 36^{\prime \prime} \mathrm{W}$, elevation of $10.4 \mathrm{~m}$ above sea level) with annual air temperature of 11 to $33{ }^{\circ} \mathrm{C}$ and precipitation of 965.2 to $1727.2 \mathrm{~mm}$ (USDA-NRCS, 2015). The soil at the experimental site was Immokalee fine sand, classified as Arenic, Alaquods, Sandy, Siliceous, Hyperthermic with a nearly flat slope $(0 \%-2 \%)$ and low runoff class with poor natural drainage (USDA-NRCS, 2015). The depth of seasonal high water table can be from 15 to $46 \mathrm{~cm}$ with low available water storage in the soil profile (USDA-NRCS, 2015) and saturated hydraulic conductivity of $15.82 \mathrm{~cm} \cdot \mathrm{h}^{-1}$ at the first $15 \mathrm{~cm}$ of soil depth (Kadyampakeni et al., 2014).

Before tomato beds (height $20 \mathrm{~cm}$ and width $81 \mathrm{~cm}$ ) were made, the soil at the study site was irrigated using a seepage system to maintain soil moisture near field capacity and ensure adequate moisture condition for bed formation. During bed formation, Pic Clor 60 (Agrian, Fresno, CA; active ingredient chloropicrin and 1,3-dichloropropene at 59.6\% and $39 \%$, respectively) was applied as a fumigant at the rate of $223 \mathrm{~kg} \cdot \mathrm{ha}^{-1}$ and immediately covered with polyethylene mulch (Berry plastics, Morrow, GA). A $0.8 \mathrm{mil}$ white/black (black side up during spring and white side up during fall) was installed during each of the two growing seasons. All the beds had two drip lines (thin-wall drip lines, 5 mil streamline Plus 630 series by Netafilm, Fresno, CA) placed on the soil surface under the polyethylene mulch, one for irrigation and one for fertigation. Tomato seedlings (variety Charger by Sakata, Morgan Hill, CA) were transplanted at 0.6-m plant spacing in a single row $21 \mathrm{~d}$ after bed preparation. Treatment plots were arranged in a randomized complete block design with four replicate plots. Each plot consisted of three adjacent rows ( $18 \mathrm{~m}$ long at $1.8 \mathrm{~m}$ between rows) each per treatment.

In both seasons, irrigation applications following the University of Florida recommendations (T1) that uses historic average daily Penman reference ET for each month of the year (HI, Zotarelli et al., 2016), was compared with three irrigation application rates of real-time and location-specific irrigation schedules. The daily amount of irrigation applied for TI was determined from the recommended ETo data for Southwest Florida (Table 1; Zotarelli et al., 2016) using the following equation:

$$
E T c=\left(\frac{E T o * K c}{0.95}\right)
$$

where ETo is the corresponding monthly reference ET value for Southwest Florida (Table 1), Kc is the crop coefficient value corresponding to a specific crop growth stage (Table 2), and 0.95 is the system efficiency used for drip irrigation system (Zotarelli et al., 2016).

Irrigation schedules from the real-time and location-specific scheduling method were applied at $66 \%$ (T2), 100\% (T3), and $150 \%$ (T4) of the SI App recommended rate. SI App is an ET-based model designed as a smartphone application using ETo from FAO Penman-Monteith procedure (Allen et al., 1998) and Kc to determine crop water requirements (Migliaccio et al., 2016). At the time of scheduling, the SI App automatically connects to the Florida Automated Weather Network and Georgia Automated Environmental Monitoring Network stations for specific scheduling locations in Florida and Georgia, respectively. SI App used meteorological data of the previous $5 \mathrm{~d}$ before the scheduling time from the Florida Automated Weather Network station located within $0.5 \mathrm{~km}$ of the research site to calculate ET, whereas $\mathrm{Kc}$ values were determined based on the time between the planting and scheduling dates (Migliaccio et al., 2016). Both T2 and T4 are within or close to irrigation application rates for low and high irrigation levels for tomato crop commonly found in the literature (Monte et al., 2013; Nangare et al., 2016).

Daily irrigation applications were determined or scheduled weekly using both scheduling methods during both seasons at $95 \%$ system efficiency. Although both scheduling methods are ET-based, irrigation scheduled by both methods could potentially differ due to the differences in the assumptions behind each scheduling method. Irrigation scheduling for $\mathrm{T} 1$ is based on historical average weather data with one ET value for a region of the state (Table 1; Zotarelli et al., 2016), whereas irrigation scheduling for SI treatments (T2, T3, T4) is based on real-time, locationspecific weather information (Migliaccio et al., 2014).

The amount of irrigation water applied to each treatment was measured and recorded by a flow meter (M $3.81 \mathrm{~cm}$ size by Netafilm, Fresno, CA) for each irrigation line. Two drip lines per bed with emitter spacing of $31 \mathrm{~cm}$ and flow rate of $0.91 \mathrm{~L} \cdot \mathrm{h}^{-1}$ (at $15 \mathrm{PSI}$ water pressure) each were used throughout the study. A 15-PSI irrigation pressure regulator (Senninger Irrigation Inc., Orlando, FL) was installed per treatment to obtain a precise flow rate and maintain constant pressure along the drip lines. Daily total irrigation time was divided into two or three (depending on the irrigation volume) irrigation events controlled by hose-end irrigation timer (Model IZEHTMR; Rain Bird, Azusa, CA). The irrigation time at each irrigation event

Table 1. Historical Penman method reference evapotranspiration for six Florida regions in $\mathrm{m}^{3} \cdot \mathrm{ha}^{-1} \mathrm{per}$ day. $^{z}$

\begin{tabular}{lcccccc}
\hline Month & Northwest & Northeast & Central & Central West & Southwest & Southeast \\
\hline January & 15.23 & 17.77 & 17.77 & 17.77 & 20.31 & 20.31 \\
February & 17.77 & 20.31 & 25.39 & 25.39 & 27.93 & 27.93 \\
March & 25.39 & 25.39 & 30.46 & 33.01 & 33.01 & 33.01 \\
April & 33.01 & 35.54 & 40.62 & 40.62 & 43.16 & 43.16 \\
May & 40.62 & 40.62 & 45.69 & 45.69 & 45.69 & 45.69 \\
June & 43.16 & 40.62 & 45.69 & 45.69 & 45.69 & 43.16 \\
July & 43.16 & 40.62 & 43.16 & 43.16 & 45.69 & 45.69 \\
August & 38.08 & 38.08 & 43.16 & 40.62 & 43.16 & 40.62 \\
September & 33.01 & 33.01 & 35.54 & 35.54 & 38.08 & 35.54 \\
October & 22.85 & 25.39 & 27.93 & 27.93 & 30.46 & 30.46 \\
November & 17.77 & 17.77 & 20.31 & 20.31 & 22.85 & 22.85 \\
December & 12.70 & 15.23 & 15.23 & 15.23 & 17.77 & 17.77 \\
\hline
\end{tabular}

${ }^{\mathrm{z}}$ Adapted from Zotarelli et al. (2016).

Table 2. Tomato growth stages, Kc values, and duration for open field tomato production during the Fall 2015 and the Spring 2016 production seasons in Immokalee, FL.

\begin{tabular}{|c|c|c|c|c|c|}
\hline \multirow{2}{*}{$\begin{array}{l}\text { Crop growth } \\
\text { stage }\end{array}$} & \multirow{2}{*}{$\begin{array}{c}\text { Kc } \\
\text { values }^{z}\end{array}$} & \multicolumn{2}{|c|}{ Kc duration (DAT) } & \multicolumn{2}{|c|}{ Period of the yr (mo.) } \\
\hline & & $\mathrm{TI}$ & $\mathrm{T} 2, \mathrm{~T} 3, \mathrm{~T} 4$ & Fall 2015 & Spring 2016 \\
\hline 1 & 0.4 & $0-14$ & $0-18$ & 14 Sept. to 28 Sept. & 3 Feb. to 24 Feb. \\
\hline 2 & 0.75 & $15-35$ & $19-37$ & 29 Sept. to 12 Oct. & 25 Feb. to 9 Mar. \\
\hline 3 & 1.0 & $36-84$ & $38-83$ & 13 Oct. to 7 Dec. & 10 Mar. to 27 Apr. \\
\hline 4 & 1.0 & $85-96$ & $84-95$ & 8 Dec. to 19 Dec. & 28 Apr to 11 May \\
\hline 5 & 0.85 & 100 -last harvest & 96-last harvest & 20 Dec. to 23 Dec. & 12 May to 31 May \\
\hline
\end{tabular}

${ }^{\mathrm{z}}$ Values obtained from Zotarelli et al. (2016) and are based on fixed time (days) after transplant.

$\mathrm{Kc}=$ crop coefficient; DAT $=$ days after transplanting; $\mathrm{TI}=$ irrigation scheduling based on historic ET average weather information; T2, 3, and $4=$ irrigation scheduling based on real-time and location specific ET-based schedule at $66 \%, 100 \%$, and $150 \%$, respectively; ET = evapotranspiration. 
was determined based on the irrigation application volume and the emitter flow rate.

Fertilizer application was the same for all treatments and applied according to UF/IFAS recommendations (Liu et al., 2016), applied as $25 \%$ preplant nitrogen $(\mathrm{N})$ and potassium (K) using N-P-K ammonium-nitrate fertilizer 18-0-18 (Griffin Fertilizer Co., Frostproof, FL) and $75 \% \mathrm{~N}$ and $\mathrm{K}$ and $100 \%$ phosphorus (P) using N-P-K ammoniumnitrate fertilizer 20-2-20 (Peters Inc., Allentown, PA) during fertigation. The total amount nutrient applied was 224-4-224 $\mathrm{kg} \cdot \mathrm{ha}^{-1}(\mathrm{~N}-\mathrm{P}-\mathrm{K})$ during each season. Fertigation was conducted twice a week for all treatments. During fertigation, the required amount of fertilizer was dissolved in $19 \mathrm{~L}$ of water for each treatment and injected into the drip lines using a pressure pump (12 VDC, 1.8 GPM; SHURflo, Cypress, CA).

Crop biomass estimation, nutrient accumulation, and yield. Unless otherwise stated, all samples were collected and measurements taken from the middle row of each plot with end plants of the center row and all plants on the outer two rows acting as buffers.

Samplings from both aboveground (leaves, stems, and fruits) and below ground (roots) biomass were collected every $30 \mathrm{~d}$ after transplanting (DAT) except for fruit sampling that started at 60 DAT. One plant representing the plot population was selected from each replicate of each treatment (Hartz and Bottoms, 2009), cut at the soil line, and separated into leaves, stems, root, and fruits. Root samples were collected considering plant total root biomass in the soil (Ehadaie et al., 2003; Rens et al., 2015). For this sampling, the soil around the selected plant was carefully removed to obtain every part of the root from the soil. Upon removing the roots, the removed soil was put back in the bed and covered with the polyethylene mulch. Root samples were washed to remove soil particles before drying. Biomass dry weights were obtained by placing the sample in a $65{ }^{\circ} \mathrm{C}$ oven for $3 \mathrm{~d}$ (leaves) and 1 week (stems, fruits, and roots). Upon drying, samples were weighed and ground for nutrient analyses. All biomass samples were analyzed for $\mathrm{N}, \mathrm{P}$, and $\mathrm{K}$ concentrations in the plant tissues. The tissue concentrations of total $\mathrm{P}$ and $\mathrm{K}$ were determined in a dry ash digest using an inductively coupled plasma system (OES Optima 7000 DV; PerkinElmer, Santa Clara, CA). Tissue total $\mathrm{N}$ concentration was determined using the NA2500 C/N analyzer (Thermoquest CE Instruments, Wigan, UK) as described by Kadyampakeni (2012).

Tomato yield was obtained by picking fruits from 15 plants per plot at the mature green stage. Three harvests were conducted at each of the production seasons. Harvested fruits were graded based on U.S. Department of Agriculture standards as medium (5.72$6.43 \mathrm{~cm}$ fruit diameter), large $(6.35-7.00 \mathrm{~cm})$, extra-large (more than $7.00 \mathrm{~cm}$ ), and unmarketable mature green and color fruits (USDA, 1997). The weights of both marketable and unmarketable fruits were recorded in $\mathrm{t} \cdot \mathrm{ha}^{-1}$.
Statistical analysis. Analysis of variance was conducted using GLM procedure of SAS, Version 9.3 (SAS Institute Inc., Cary, NC). A one factorial model was developed using a randomized complete block design using irrigation rate as the main effect. Except for yield, all data analysis (plant biomass, nutrient uptake, and partitioning) were classified by DAT to determine the effects of irrigation rates over time. Unless otherwise stated, all data analysis considered four replicates per treatment. All data were analyzed for significant interactions between season and DAT. Data were separated by season and sampling dates within each season when significant interactions were observed. Duncan's multiple range test was used $(\alpha=0.05)$ as mean separation when significant differences were observed among treatments.

\section{Result and Discussion}

Weather condition. Temperature patterns were different for fall and spring seasons. Daily maximum and minimum air temperature ranged from 33 to $23^{\circ} \mathrm{C}$ and 24 to $11^{\circ} \mathrm{C}$, respectively, during the fall season and from 33 to $16{ }^{\circ} \mathrm{C}$ and 20 to $3{ }^{\circ} \mathrm{C}$, respectively, during the spring season (Fig. 1). The temperature pattern in fall season was warmer at the beginning of the season than late in the season, whereas daily air temperature increased from the start to the end of spring season. The relatively lower temperature during the spring season extended production season by 2 weeks (total of 17 weeks) compared with 15 weeks during the fall season. A similar observation was reported by Ozores-Hampton et al. (2015) for tomato production during Spring of 2006 when total production season was extended to 20 weeks due to lower temperatures during the production season.

As with temperature patterns, precipitation patterns also were different for both seasons (Fig. 2). Cumulative precipitation was greater $(279.4 \mathrm{~mm})$ during fall season compared with spring season $(107 \mathrm{~mm})$. Sixty-five percent of the total precipitation $(180 \mathrm{~mm})$ in the fall season occurred during the first 10 DAT, which was greater than total precipitation during the spring season $(107 \mathrm{~mm})$. Because of the unusually high amount of precipitation early in the fall season, irrigation was delayed until 5 weeks after transplanting. However, irrigation was not delayed during the spring season and was started immediately after transplanting. Total irrigated water applied for each treatment was lower during the fall season (Fig. 3) due to the high precipitation and a relatively shorter season during fall. However, a similar crop water application pattern was observed for all treatments in both seasons where total irrigation depths increased in the order of $\mathrm{T} 2<\mathrm{T} 3<\mathrm{T} 1<\mathrm{T} 4$. Irrigation at T3 was $22 \%$ and $16 \%$ lower compared with $\mathrm{T} 1$ for fall and spring seasons, respectively.

Water use. Although both scheduling methods (HI and SI) are ET-based, the differences in irrigation scheduled by both methods in both production seasons were principally due to the differences in the assumptions behind each scheduling method. Irrigation scheduling using $\mathrm{HI}$ is based on historical average weather data; hence, daily values of water requirement for vegetable production using $\mathrm{HI}$ could vary up to $25 \%$ higher or lower (Zotarelli et al., 2016). Because SI irrigation schedules were based on real-time, location-specific weather data

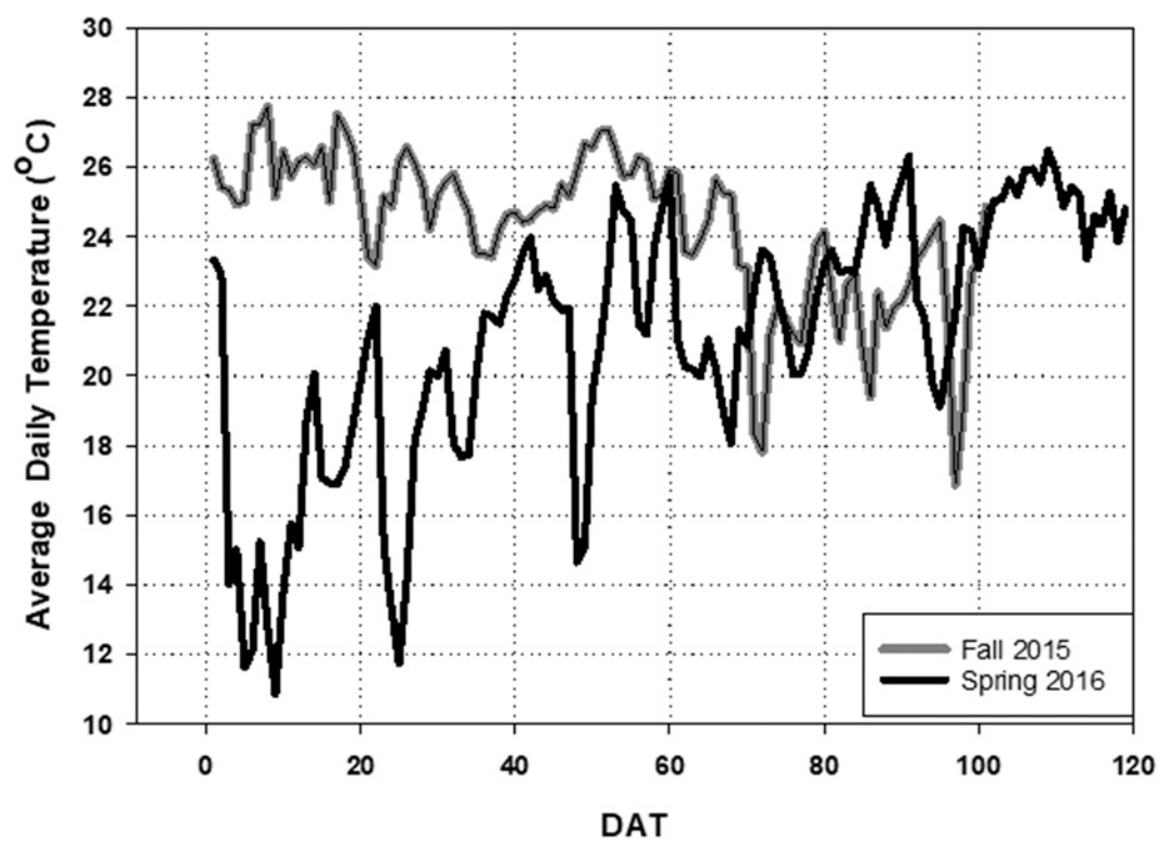

Fig. 1. Daily average temperature during Fall 2015 and Spring 2016 production seasons in Immokalee, FL. (Data obtained from Florida Automated Weather Network.) Period between 14 Sept. and 23 Dec. during Spring 2015 and 3 Feb. to 31 May during Fall 2016. DAT = days after transplanting. 


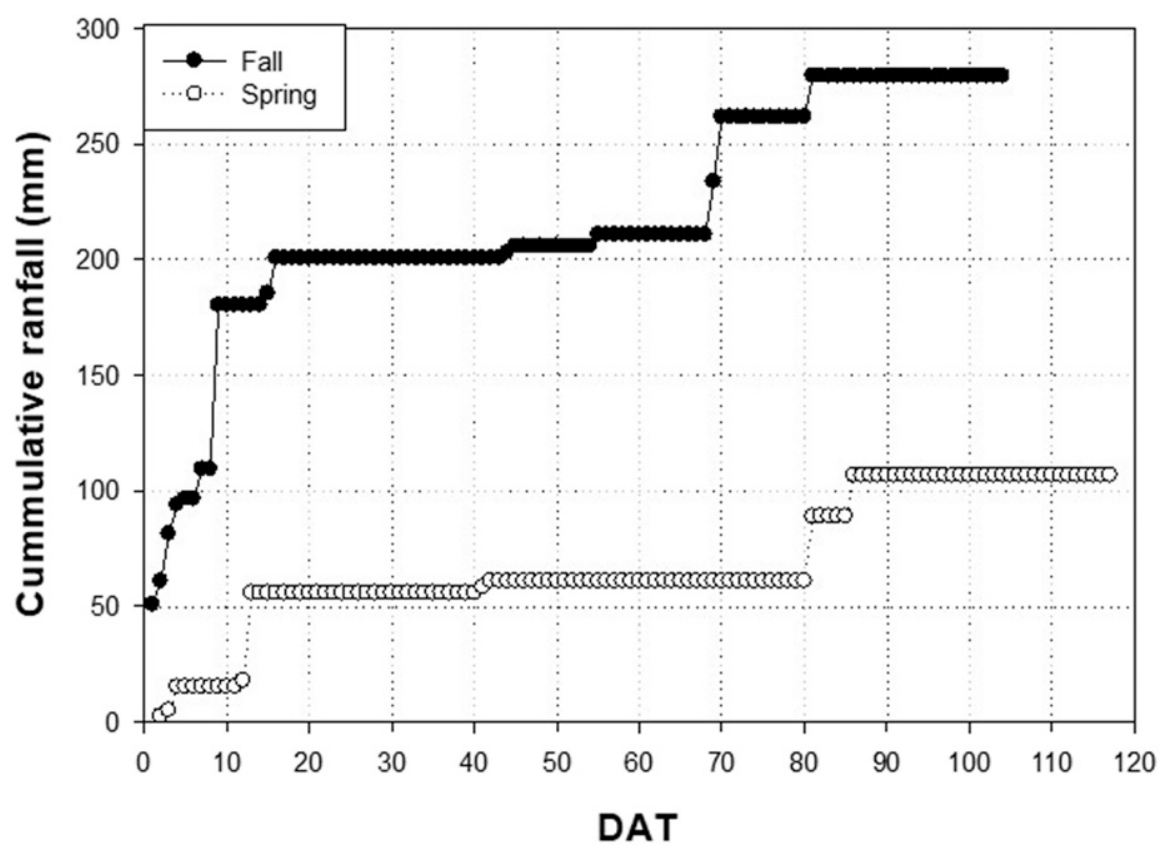

Fig. 2. Cumulative rainfall during Fall 2015 and Spring 2016 production seasons in Immokalee, FL. (Data obtained from Florida Automated Weather Network.) Period between 14 Sept. and 23 Dec. during Spring 2015 and 3 Feb. and 31 May during Fall 2016. DAT = days after transplanting.

(Migliaccio et al., 2014), SI App provides opportunity for a more accurate irrigation schedule and, hence, greater water savings compared with HI. A similar result was reported by Vellidis et al. (2014) in cotton (Gossypium spp), where irrigation schedule based on real-time and location-specific weather information significantly reduced irrigation water compared with the standard checkbook method. The checkbook method estimates crop irrigation requirement by replacing the maximum expected weekly crop water use minus the measured precipitation (Vellidis et al., 2014).

Plant biomass and dry matter partitioning. Significant differences were observed between seasons and DAT; therefore, plant biomass and dry matter partitioning were separately analyzed by season and sampling dates within each season. Early in the seasons (30 DAT), tomato total dry matter accumulation was generally lower for spring season (ranged from 29 to $47 \mathrm{~kg} \cdot \mathrm{ha}^{-1}$ ) than for fall (ranged from 354 to $454 \mathrm{~kg} \cdot \mathrm{ha}^{-1}$ ) (Table 3). However, as temperatures increased in the spring season, total dry biomass accumulation (at 90 DAT) increased significantly and was similar (for all treatments) to the biomass accumulation during fall season. This is because biological processes are temperature dependent (Russelle et al., 1984) and plant growth and development are more of a function of heat accumulation than time (Neild and Seeley, 1977). Therefore, reduced growth and biomass accumulation early (30 DAT) during spring season was due to lower air temperature. Within each season, plant dry matter accumulation was unaffected $(P>0.05)$ by irrigation rates and scheduling methods at all sampling periods and sampling categories

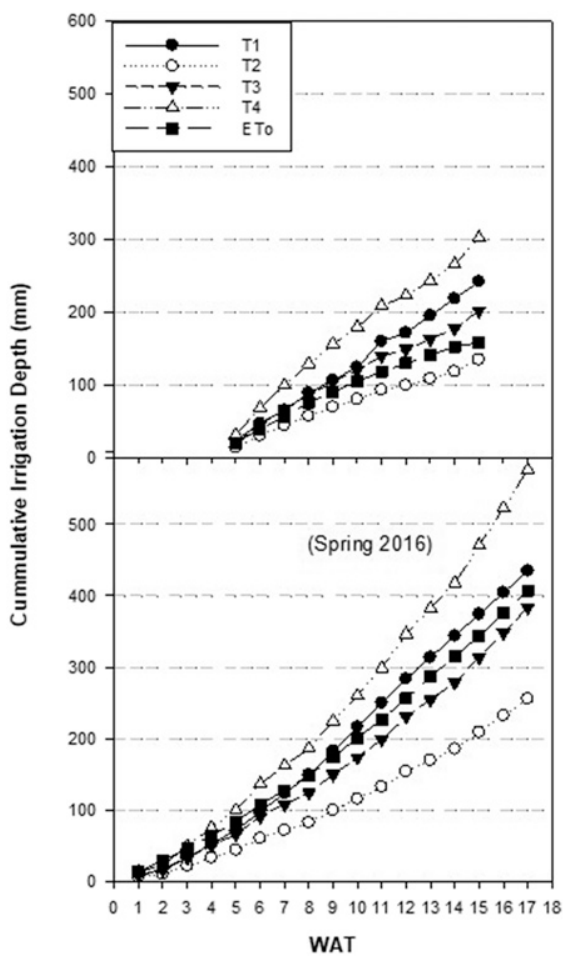

Fig. 3. Cumulative irrigation depth for drip irrigated fresh market tomato during Fall 2015 and Spring 2016 in Immokalee, FL. Irrigation started 5 weeks after transplanting during fall season due to high frequency of rainfall early in the season. WAT $=$ weeks after transplanting.

season, root biomass accumulation was sig nificantly greater for lower irrigation rate (T2) than the higher irrigation rates (Table 3). This result was consistent with that of Ngouajio et al. (2007), who reported increase root development in a reduced irrigation in open-field tomato production. However, this conclusion could not be reached in this study. This is because, during a relatively drier spring season, root dry matter accumulation was similar $(P>0.05)$ among all irrigation rates and scheduling methods. Total season dry biomass accumulation was similar to that reported by Zotarelli et al. (2009a) for tomato production grown with similar irrigations. These results suggest that perhaps under a sandy soil condition, a moderately lower irrigation regime may be sufficient for tomato growth and development. This could possibly be achieved by adjusting tomato Kc (crop coefficient) values to lower water applications. Therefore, more study on tomato $\mathrm{Kc}$ and water use would be required to effectively adjust tomato $\mathrm{Kc}$ and water requirement to increase tomato water use efficiency and mitigate possible environmental impacts.

Fruit yield and grade distribution. Significant differences were observed between seasons for tomato yield and grade distribution; therefore, data were analyzed by season. During fall season, no significant differences in yield $(P=0.77)$ were observed among treatments for the harvested medium-grade fruit category; however, for this same category, yield from T3 was significantly $(P=$ 0.04 ) greater compared with other irrigation rates during the spring season (Table 4). Yield of large-grade tomato fruit was more consistent by treatment with T3 producing significantly $(P=0.02$ fall; $P=0.006$ spring $)$ greater yield in both seasons. No effect of irrigation rates was observed in either season for the extra-large and unmarketable fruit categories. The effects of irrigation rates were significant $(P=0.03$, spring; $P=0.01$, fall) on the total season marketable yield (TMY) in both seasons. The TMY was greater for tomato plants in $\mathrm{T} 3$ irrigation regime for spring season. During the fall season, TMY from T3 was statistically similar with T2 and greater than TMY obtained from the higher irrigation rates (T1 and T4). A similar TMY observed for T3 and T2 during fall season could be due to two possible reasons. First, the increase in precipitation during early fall season could have enhanced general plant performance in the $\mathrm{T} 2$ irrigation regime early in the season. Second, because reproductive features of tomato plants are more susceptible to stress conditions compared with vegetative growth (Peet and Willits, 1998), similar yield between T3 and T2 treatments suggested no major water stress for T2 during the fall. This could be a possible indication that tomato water requirements may not be as high as previously reported (Zotarelli et al., 2016). Therefore, more studies on tomato water requirement would be recommended for a more efficient water use in Florida tomato production. In addition, the lower TMY for higher irrigation rates (T4 and T1) suggested possible nutrient leaching, especially on 
Table 3. Tomato plant dry matter accumulation at 30,60, and $90 \mathrm{~d}$ after transplanting (DAT) during Fall 2015 and Spring 2016 seasons in Immokalee, FL.

\begin{tabular}{|c|c|c|c|c|c|c|}
\hline DAT & Treatment & Leaves & Stem & Root & Fruit & Total biomass \\
\hline & & & Fall 2 & $\mathrm{~kg} \cdot \mathrm{ha} a^{-1}$ & & \\
\hline \multirow[t]{4}{*}{30} & $\mathrm{~T} 1$ & 183 & 149 & 20 & - & 354 \\
\hline & $\mathrm{T} 2$ & 236 & 191 & 26 & - & 454 \\
\hline & T3 & 228 & 179 & 26 & - & 434 \\
\hline & $\mathrm{T} 4$ & 179 & 161 & 20 & - & 361 \\
\hline$P$ value & & 0.11 & 0.11 & 0.17 & - & 0.19 \\
\hline \multirow[t]{4}{*}{60} & $\mathrm{~T} 1$ & 865 & 815 & 62 & 1,789 & 3,532 \\
\hline & $\mathrm{T} 2$ & 883 & 824 & 62 & 1,738 & 3,509 \\
\hline & T3 & 842 & 753 & 71 & 1,868 & 3,535 \\
\hline & $\mathrm{T} 4$ & 654 & 676 & 58 & 1,462 & 2,851 \\
\hline$P$ value & & 0.09 & 0.66 & 0.61 & 0.89 & 0.43 \\
\hline \multirow[t]{4}{*}{90} & $\mathrm{~T} 1$ & 647 & 9363 & $74 b^{z}{ }^{z}$ & 1,121 & 2,778 \\
\hline & $\mathrm{T} 2$ & 1,192 & 1,054 & 95 a & 1,277 & 3,619 \\
\hline & $\mathrm{T} 3$ & 992 & 872 & $85 \mathrm{ab}$ & 1,349 & 3,300 \\
\hline & $\mathrm{T} 4$ & 706 & 743 & $63 \mathrm{c}$ & 1,302 & 2,816 \\
\hline \multirow[t]{2}{*}{$P$ value } & & 0.56 & 0.26 & 0.004 & 0.29 & 0.15 \\
\hline & \multicolumn{6}{|c|}{ Spring $2016\left(\mathrm{~kg} \cdot \mathrm{ha^{-1 }}\right)$} \\
\hline \multirow[t]{4}{*}{30} & $\mathrm{~T} 1$ & 22 & 9 & 4 & - & 36.17 \\
\hline & $\mathrm{T} 2$ & 23 & 7 & 5 & - & 35.81 \\
\hline & T3 & 28 & 12 & 5 & - & 46.67 \\
\hline & $\mathrm{T} 4$ & 17 & 7 & 3 & - & 28.80 \\
\hline$P$ value & & 0.45 & 0.19 & 0.43 & - & 0.33 \\
\hline \multirow[t]{4}{*}{60} & T1 & 867 & 766 & 62 & 271 & 1,968 \\
\hline & $\mathrm{T} 2$ & 764 & 641 & 58 & 325 & 1,788 \\
\hline & T3 & 791 & 670 & 49 & 284 & 1,795 \\
\hline & $\mathrm{T} 4$ & 715 & 277 & 51 & 277 & 1,322 \\
\hline$P$ value & & 0.48 & 0.32 & 0.9 & 0.42 & 0.45 \\
\hline \multirow[t]{4}{*}{90} & $\mathrm{~T} 1$ & 1,186 & 887 & 63 & 481 & 2,618 \\
\hline & $\mathrm{T} 2$ & 1,210 & 741 & 55 & 796 & 2,803 \\
\hline & T3 & 1,279 & 989 & 71 & 739 & 3,079 \\
\hline & $\mathrm{T} 4$ & 1,067 & 1,076 & 75 & 424 & 2,642 \\
\hline$P$ value & & 0.51 & 0.29 & 0.24 & 0.07 & 0.52 \\
\hline
\end{tabular}

${ }^{\mathrm{z}}$ Means in bold are significantly different at $P=0.004$.

$\mathrm{TI}=$ irrigation scheduling based on historic ET average weather information; T2, 3, and $4=$ irrigation scheduling based on real-time and location specific ET-based schedule at $66 \%, 100 \%$, and $150 \%$, respectively; ET = evapotranspiration.

Table 4. Tomato productivity during Fall 2015 and Spring 2016 in Immokalee, FL. ${ }^{\mathrm{z}}$

\begin{tabular}{lccccc}
\hline Treatment & Medium & Large & Extra-large & Total marketable & Unmarketable \\
\hline T1 & 5.26 & $9.24 \mathrm{~b}$ & 55.66 & $70.16 \mathrm{~b}$ & 9.46 \\
T2 & 4.92 & $13.86 \mathrm{ab}$ & 67.97 & $87.96 \mathrm{ab}$ & 4.52 \\
T3 & 7.04 & $17.67 \mathrm{a}$ & 70.37 & $95.08 \mathrm{a}$ & 10.16 \\
T4 & 5.64 & $11.34 \mathrm{~b}$ & 54.01 & $70.99 \mathrm{~b}$ & 9.1 \\
$P$ value & 0.77 & 0.02 & 0.15 & 0.03 & 0.37 \\
& & & & \\
T1 & $6.86 \mathrm{~b}$ & $25.13 \mathrm{a}$ & 33.04 & $65.03 \mathrm{~b}$ & 14.91 \\
T2 & $3.76 \mathrm{~b}$ & $16.24 \mathrm{~b}$ & 37.23 & $57.22 \mathrm{~b}$ & 12.78 \\
T3 & $10.86 \mathrm{a}$ & $28.55 \mathrm{a}$ & 42.15 & $81.56 \mathrm{a}$ & 16.35 \\
T4 & $6.48 \mathrm{~b}$ & $25.00 \mathrm{a}$ & 35.14 & $66.22 \mathrm{~b}$ & 14.35 \\
$P$ value & 0.04 & 0.006 & 0.27 & 0.01 & 0.43 \\
\hline
\end{tabular}

${ }^{\mathrm{z}}$ Reported values are mean of three replicates per treatment. Means values with different letter show significantly different at $P \leq 0.05$.

$\mathrm{TI}=$ irrigation scheduling based on historic ET average weather information; T2, 3, and $4=$ irrigation scheduling based on real-time and location specific ET-based schedule at $66 \%, 100 \%$, and $150 \%$, respectively; $\mathrm{ET}=$ evapotranspiration.

sandy soil. Although drip irrigation provides a more efficient water use through a greater precision in water placement and reduction of problems associated with nutrient leaching (Hartz, 1993; Locascio and Myers, 1974), excessive water application can potentially reduce tomato yield because of nutrient leaching (Locascio and Smajstrla, 1989).
Nutrient (N, $P$, and $K$ ) accumulation and partitioning. Significant differences were observed between seasons and DAT for plant nutrient accumulation and partitioning; therefore, data were analyzed by season and sampling dates within each season. The results of plant nutrient accumulations and partitioning are presented in Tables 5 and 6 .
Plant nutrient accumulation was lower early (30 DAT) during spring season compared with fall season. This is due to the relatively lower air temperature early in spring season resulting in lower plant growth hence lower nutrient uptake and accumulation. However, as temperature increased during the spring season, plant nutrient accumulation increased and was similar to the fall season at 90 DAT.

In both seasons, no significant differences were observed among irrigation rates on $\mathrm{N}$ accumulations at $30 \mathrm{DAT}$ and 60 DAT for leaves, stem, fruits, roots, and total plant. However, later in the season (90 DAT), irrigation rates had significant $(P \leq 0.05)$ effects on plant tissue $\mathrm{N}$ accumulation and partitioning in both seasons. During the fall season, fruit $\mathrm{N}$ and total $\mathrm{N}$ accumulation were significantly greater for the T3 irrigation treatment compared with plants in higher irrigation regimes (T1 and T4). Similarly, during the spring season, leaf $\mathrm{N}$ and total plant $\mathrm{N}$ accumulation were significantly greater for $\mathrm{T} 3$ compared with $\mathrm{T} 1$ and $\mathrm{T} 4$. In both seasons, $\mathrm{N}$ accumulation in the fruits were statistically similar for $\mathrm{T} 1$ and $\mathrm{T} 2$ at $70 \mathrm{~kg} \cdot \mathrm{ha}^{-1}, 56 \mathrm{~kg} \cdot \mathrm{ha}^{-1}$ and $95 \mathrm{~kg} \cdot \mathrm{ha}^{-1}, 94 \mathrm{~kg} \cdot \mathrm{ha}^{-1}$ for fall and spring seasons, respectively. Compared with $\mathrm{T} 3$, the lower $\mathrm{N}$ accumulation in the higher irrigation regimes ( $\mathrm{T} 1$ and T4) suggested possible $\mathrm{N}$ leaching below the root zone, especially during maximum $\mathrm{Kc}$ demand, which corresponds to the period of maximum irrigation application. This is because in sandy soils, nitrate $\left(\mathrm{NO}_{3}{ }^{-}-\mathrm{N}\right)$ moves with the wetting front; thus, $\mathrm{N}$ leaching is intrinsically linked with the soil water dynamics (Zotarelli et al., 2007). Therefore, excessive irrigation and/or $\mathrm{N}$ application rate on sandy soils could greatly increase the potential risk of $\mathrm{N}$ leaching (Knox and Moody, 1991; McNeal et al., 1995). The problems associated with $\mathrm{NO}_{3}^{-}-\mathrm{N}$ leaching could be significant on sandy soils because of greater water infiltration rate and lower $\mathrm{NO}_{3}{ }^{-}-$ $\mathrm{N}$ retention capacity (Sainju et al., 2003).

No effect of irrigation rates was observed for $\mathrm{P}$ uptake and accumulation at all sampling periods in both seasons. Unlike N, P is less mobile in soils (Sainju et al., 2003), and leaching of $\mathrm{P}$ is negligible because of precipitation and adsorption to mineral surfaces. This is because the loss of $\mathrm{P}$ from agricultural land is often attributed to surface runoff (Pote et al., 1996; Sims et al., 1998) and drainage water (Sims et al., 1998).

Similarly, the effects of irrigation rates on $\mathrm{K}$ uptake was less evidence compared with $\mathrm{N}$ in both seasons. During the fall season, significant differences were observed for $\mathrm{K}$ accumulation only for the stem at 60 DAT and total plant $\mathrm{K}$ accumulation at 90 DAT (Table 5). In both cases, the pattern of $K$ accumulation in tomato plants was similar to that of $\mathrm{N}$, where accumulation was lower at greater irrigation rates. However, irrigation rate did not have a significant effect on plant $\mathrm{K}$ accumulation and uptake for all sampled tissues (leaves, stem, fruit, and root) and total plant accumulated $\mathrm{K}$ during the spring season (Table 6). Therefore, unlike $\mathrm{N}$ 
Table 5. Effect of irrigation rates on nitrogen $(\mathrm{N})$, phosphorus $(\mathrm{P})$, and potassium $(\mathrm{K})$ accumulation in tomato plants with drip irrigation at different days after transplanting (DAT) during Fall 2015 in Immokalee, FL. ${ }^{2}$

\begin{tabular}{|c|c|c|c|c|c|c|c|c|c|c|c|c|c|c|c|c|}
\hline \multirow[b]{2}{*}{ DAT } & \multirow[b]{2}{*}{ Treatment } & \multicolumn{5}{|c|}{$\mathrm{N}$ accumulation $\left(\mathrm{kg} \cdot \mathrm{ha}^{-1}\right)$} & \multicolumn{5}{|c|}{$\mathrm{P}$ accumulation $\left(\mathrm{kg} \cdot \mathrm{ha}^{-1}\right)$} & \multicolumn{5}{|c|}{$\mathrm{K}$ accumulation $\left(\mathrm{kg} \cdot \mathrm{ha}^{-1}\right)$} \\
\hline & & Leaves & Stems & Fruits & Roots & TN & $\overline{\text { Leaves }}$ & Stems & Fruits & Roots & TP & Leaves & Stems & Fruits & Roots & TK \\
\hline & $\mathrm{T} 2$ & 8.44 & 5.78 & - & 0.65 & 14.88 & 1.42 & 0.98 & - & 0.07 & 2.47 & 7.80 & 12.09 & - & 0.80 & 20.69 \\
\hline$P$ value & & 0.64 & 0.06 & & 0.31 & 0.47 & 0.80 & 0.81 & & 0.77 & 0.81 & 0.38 & 0.46 & & 0.59 & 0.40 \\
\hline 60 & $\mathrm{~T} 1$ & 32.03 & 16.55 & 63.53 & 1.31 & 117.01 & 3.03 & 3.46 & 14.58 & 0.17 & 21.23 & 17.88 & $76.40 \mathrm{a}$ & 99.55 & 1.46 & 195.29 \\
\hline & $\mathrm{T} 4$ & 32.52 & 14.19 & 54.95 & 0.81 & 100.64 & 2.95 & 3.44 & 14.05 & 0.15 & 20.59 & 16.20 & $36.87 \mathrm{~b}$ & 118.62 & 1.41 & 173.10 \\
\hline$P$ value & & 0.24 & 0.09 & 0.95 & 0.17 & 0.65 & 0.28 & 0.58 & 0.60 & 0.42 & 0.39 & 0.24 & 0.03 & 0.12 & 0.76 & 0.08 \\
\hline 90 & $\mathrm{~T} 1$ & $26.25 \mathrm{~b}$ & 19.15 & $36.51 \mathrm{~b}$ & 1.92 & 83.82 c & 3.48 & 4.03 & 13.15 & 0.26 & 20.92 & 15.96 & 27.14 & 71.61 & 1.77 & $116.48 \mathrm{~b}$ \\
\hline & $\mathrm{T} 2$ & $45.64 \mathrm{a}$ & 22.85 & 55.78 ab & 1.66 & $125.94 \mathrm{ab}$ & 4.67 & 4.42 & 12.76 & 0.20 & 22.03 & 26.80 & 32.01 & 80.57 & 1.56 & 140.94 ab \\
\hline & T3 & $40.68 \mathrm{ab}$ & 24.35 & 69.78 a & 1.75 & 136.41 a & 3.94 & 4.91 & 16.64 & 0.21 & 22.70 & 26.67 & 31.86 & 99.50 & 1.50 & $159.53 \mathrm{a}$ \\
\hline & T4 & 32.37 ab & 18.44 & $44.77 \mathrm{~b}$ & 1.35 & 96.92 bc & 3.81 & 3.44 & 9.79 & 0.22 & 17.25 & 19.37 & 31.86 & 76.71 & 1.45 & $115.19 \mathrm{~b}$ \\
\hline
\end{tabular}

${ }^{\mathrm{z}}$ Reported values are average mean of three replicates per treatment. Means in bold shows statistical differences. Mean with different letter show significantly different at $P \leq 0.05$.

$\mathrm{TI}=$ irrigation scheduling based on historic ET average weather information; T2, 3, and $4=$ irrigation scheduling based on real-time and location specific ETbased schedule at $66 \%, 100 \%$, and $150 \%$ respectively; ET $=$ evapotranspiration.

Table 6. Effects of irrigation rates on nitrogen $(\mathrm{N})$, phosphorus $(\mathrm{P})$, and potassium $(\mathrm{K})$ accumulation in tomato plants biomass with drip irrigation at different days after transplanting (DAT) during Spring 2016 in Immokalee, FL. ${ }^{\mathrm{z}}$

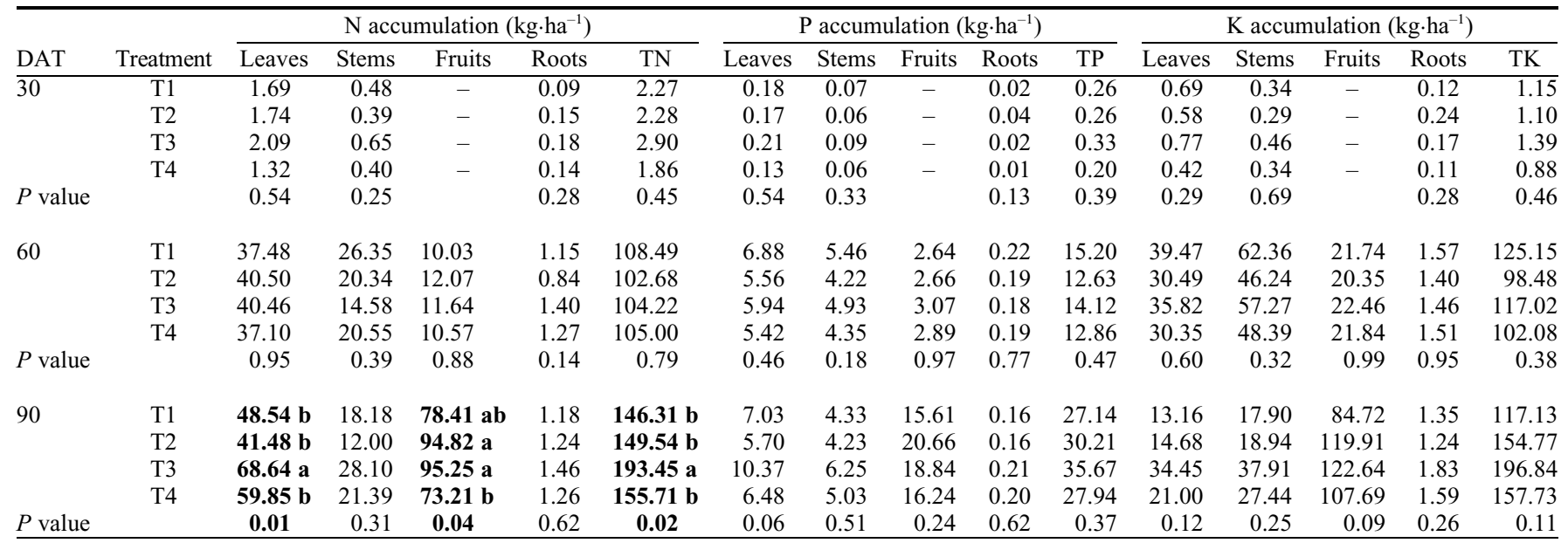

${ }^{\mathrm{z}}$ Reported values are average mean of three replicates per treatment. Means in bold shows statistical differences. Mean with different letter show significantly different at $P \leq 0.05$.

$\mathrm{TI}=$ irrigation scheduling based on historic ET average weather information; T2, 3, and 4 = irrigation scheduling based on real-time and location specific ETbased schedule at $66 \%, 100 \%$, and $150 \%$, respectively.

uptake, the observed tomato $\mathrm{K}$ uptake in this study may be considered insufficient to suggest $\mathrm{K}$ leaching at any irrigation application rate used in this study.

\section{Conclusions}

Although HI and SI are both ET-based irrigation scheduling methods, on a Florida sandy soil, irrigation schedule for open-field, fresh-market tomato production using SI resulted in lower total season water application, higher yields, and increased plant $\mathrm{N}$ accumulation compared with HI. Therefore, compared with HI, SI vegetable App reduced excessive irrigation application in open-field, fresh-market tomato production and consequently may reduce nutrient leaching, especially on sandy soils. This is because irrigation schedule from SI is location specific with real-time weather data compared with HI. The impact of high irrigation application was more evident in fruit and leaf $\mathrm{N}$ accumulation compared with stem and root biomass, resulting in significantly lower yield. Therefore, based on crop performance and water savings, irrigation based on locationspecific and real-time weather information improves irrigation scheduling accuracy in relation to actual crop water requirement in openfield tomato production.

\section{Literature Cited}

Allen, R.G., L.S. Pereira, D. Raes, and M. Smith. 1998. Crop evapotraspiration: Guidelines for computing crop requirements. FAO Irrigation and Drainage Paper No. 56. FAO, Rome, Italy.

Costa, J.M. and E. Heuvelink. 2005. The tomato crop and industry, p. 1-20. In: E. Heuvelink (ed.). Tomatoes. Cromwell Press, Trowbridge, UK.
Davis, S.L. and M.D. Dukes. 2010. Irrigation scheduling performance by evapotranspirationbased controllers. Agr. Water Mgt. 98:19-28.

Dukes, M.D. 2012. Water conservation potential of landscape irrigation smart controllers. Trans. ASABE 55:563-569.

Ehadaie, B., R.W. Whitkus, and J.G. Waines. 2003. Root biomass, water-use efficiency, and performance of wheat-rye translocations of chromosomes 1 and 2 in spring bread wheat 'Pavon'. Crop Sci. 43:710-717.

FDACS. 2017. Florida agriculture by numbers. 17 Jan. 2018. <http://www.freshfromflorida.com/ Divisions-Offices/Marketing-and-Development/ Education/For-Researchers/Florida-AgricultureOverview-and-Statistics $>$.

Hartz, T.K. 1993. Drip-irrigation scheduling for fresh-market tomato production. HortScience 28:35-37.

Hartz, T.K. and T.G. Bottoms. 2009. Nitrogen requirements of drip-irrigated processing tomatoes. HortScience 44:1988-1993. 
Hochmuth, G. and E. Hanlon. 2014. A summary of $\mathrm{N}, \mathrm{P}$, and $\mathrm{K}$ research with tomato in Florida. Univ. Florida, Inst. Food Agr. Sci., Electronic Data Info. 2 Feb. 2018. <http://edis.ifas.ufl.edu/ cv236>.

Kadyampakeni, D.M. 2012. Citrus advanced production system: Understanding water and NPK uptake and leaching in Florida flatwoods and ridge soils. Univ. Florida, Gainesville, $\mathrm{PhD}$ Diss. Abstr. 030997643.

Kadyampakeni, D.M., K.T. Morgan, A.W. Schumann, P. Nkedi-Kizza, and T. Obreza. 2014. Water use in drip- and microsprinkler-irrigated citrus trees. Soil Sci. Amer. J. 78:1351-1361.

Kirda, C., M. Cetin, Y. Dasgan, S. Topcu, H. Kaman, B. Ekici, M.R. Derici, and A.I. Ozguven. 2004. Yield response of greenhouse grown tomato to partial root drying and conventional deficit irrigation. Agr. Water Mgt. 69:191-201.

Kisekka, I., K.W. Migliaccio, M.D. Dukes, B. Schaffer, and J.H. Crane. 2010. Evapotranspirationbased irrigation scheduling and physiological response in a carambola (Averrhoa carambola $\mathrm{L}$.) orchard. Appl. Eng. Agr. 26:373-380.

Knox, E. and D.W. Moody. 1991. Influence of hydrology, soil properties, and agricultural land use on nitrogen in groundwater, p. 19-57. In: R.F. Follett, D.R. Keeney, and R.M. Cruse (eds.). Managing nitrogen for groundwater quality and farm profitability. SSSA, Madison, WI.

Liu, G., E.R. Simonne, K.T. Morgan, G.J. Hochmuth, M. Ozores-Hampton, and S. Agehara. 2016. Fertilizer management for vegetable production in Florida. Univ. Florida, Inst. Food Agr. Sci., Electronic Data Info. 2 Feb. 2018. <http:// edis.ifas.ufl.edu/cv296>.

Locascio, S.J. and A.G. Smajstrla. 1989. Dripirrigated tomato as infected by water quantity and $\mathrm{N}$ and $\mathrm{K}$ application timing. Proc. Fla. State Hort. Soc. 102:307-309.

Locascio, S.J. and J.M. Myers. 1974. Tomato response to plug-mix mulch and irrigation method. Proc. Fla. State Hort Soc. 87:126-130.

McNeal, B.L., C.D. Stanley, W.D. Graham, P.R. Gilreath, D. Downey, and J.F. Creighton. 1995. Nutrient loss trends for vegetables and citrus fields in west central Florida: I. Nitrate. J. Environ. Qual. 25:95-100.

Migliaccio, K.W., B. Schaffer, Y. Li, E. Evans, J.H. Crane, and R. Muñoz-Carpena. 2008. Assessing benefits of irrigation and nutrient management practices on a southeast Florida royal palm (Roystonea elata) field nursery. Irrig. Sci. 27:57-66.

Migliaccio, K.W., C. Fraisse, G. Vellidis, K.T. Morgan, D. Rowland, L. Zotarelli, and J.H. Debastiani Andreis. 2014. Smart irrigation apps. 1 Jan. 2018. <http://en.envirocitiesmag. com/articles/issue-8/Art3.pdf $>$.

Migliaccio, K.W., K.T. Morgan, G. Vellidis, L. Zotarelli, C. Fraisse, B.A. Zurweller, J.H. Andreis, J.H. Crane, and D.L. Rowland. 2016. Smartphone apps for irrigation scheduling. ASABE 59(1):291-301.

Monte, J.A., D.F. de Carvalho, L.O. Medici, L.D.B. da Silva, and C. Pimentel. 2013. Growth analysis and yield of tomato crop under different irrigation depths. R. Bras. Eng. Agric. Ambiental 17(9):926-931.

Morgan, K.T., T.A. Obreza, J.M. Scholberg, L.R. Parson, and T.A. Wheaton. 2006. Citrus water uptake dynamics on a sandy Florida Entisol. SSSAJ 70(1):90-97.

Morgan, K.T., L. Zotarelli, and M.D. Dukes. 2010. Use of irrigation technologies for citrus trees in Florida. HortTechnology 20:74-81.

Nangare, D.D., Y. Singh, P.S. Mumar, and P.S. Minhas. 2016. Growth, fruit yield and quality of tomato (Lycopersicon esculentum Mill.) as affected by deficit irrigation on phenological basis. Agr. Water Mgt. 171:73-79.

Neild, R.E. and W.M. Seeley. 1977. Growing degree-days predictions for corn and sorghum development and some applications to crop production in Nebraska. Nebr. Agric. Exp. Stn. Res. Bull. 280. Lincoln. Nebr.

Ngouajio, M., G. Wang, and R. Goldy. 2007. Withholding of drip irrigation between transplanting and flowering increases the yield of field-grown tomato under plastic mulch. Agr. Water Mgt. 87:285-291.

Ozores-Hampton, M., F. Di Gioia, S. Sato, E. Simonne, and K. Morgan. 2015. Effects of nitrogen rates on nitrogen, phosphorous, and potassium partitioning, accumulation, and use efficiency in seepage-irrigated fresh market tomatoes. HortScience 50:1636-1643.

Patanè, C. and S.L. Cosentino. 2010. Effects of soil water deficit on yield and quality of processing tomato under a Mediterranean climate. Agr. Water Mgt. 97:131-138.

Patanè, C., S. Tringali, and O. Sortino. 2011. Effects of deficit irrigation on biomass yield, water productivity and fruit quality of processing tomato under semi-arid Mediterranean climate conditions. Scientia Hort. 129:590-596.

Peet, M.M. and D.H. Willits. 1998. The effect of night temperature on greenhouse grown tomato yields in warm climate. Agr. For. Meteorol. 92:191-202.

Pote, D.H., T.C. Daniel, A.N. Sharpley, P.A. Moore Jr., D.R. Edwards, and D.J. Michols. 1996. Relating extractable soil phosphorus to phosphorus losses in runoff. SSSAJ. 60:855859.

Rens, L.R., L. Zotarelli, D.J. Cantliffe, P.J. Stoffella, D. Gergela, and D. Fourman. 2015. Biomass accumulation, marketable yield and quality of Atlantic Potato in response to nitrogen. Agron. J. 107:931-942.

Rowland, D.L., W.H. Faircloth, P. Payton, D.T. Tissue, J.A. Ferrell, R.B. Sorensen, and C.L. Butts. 2012. Primed acclimation of cultivated peanut (Arachis hypogaea L.) through the use of deficit irrigation timed to crop developmental periods. Agr. Water Mgt. 113:85-95.

Russelle, M.P., W.W. Wilhelm, R.A. Olson, and J.F. Power. 1984. Growth analysis based on degree days. Univ. Nebraska-Lincoln. 17 Jan. 2017. <https://pdfs.semanticscholar.org/7016/ b4b6d401cc4c98d4228ffe8845fd6e22565d.pdf >.

Sainju, U.M., R. Dris, and B. Singh. 2003. Mineral nutrition of tomato. 8 Mar. 2018. <https://
www.researchgate.net/profile/Upendra_Sainju/ publication/228960277_Mineral_nutrition_of_ tomato/links/09e41512412ac2031e000000.pdfs.

Sims, J.T., R.R. Simard, and B.C. Joern. 1998. Phosphorus loss in agricultural drainage: Historical perspective and current research. J. Environ. Qual. 27:277-293.

Topcu, S., C. Kirda, Y. Dasgan, H. Kaman, M. Cetin, A. Yazici, and M.A. Bacon. 2007. Yield response and $\mathrm{N}$-fertiliser recovery of tomato grown under deficit irrigation. Eur. J. Agron. 26(1):64-70.

USDA. 1997. United States standard for grade of fresh tomatoes. U.S. Dept. Agr., Agricultural Marketing Service, Washington, DC.

USDA. 2017. 2016 State agriculture overview Florida. USDA, National Agricultural Statistics Service, Washington, DC. 11 Apr. 2018. $<$ https://www.nass.usda.gov/Quick_Stats/Ag_ Overview/stateOverview.php?state=FLORIDA $>$.

USDA-NRCS. 2015. Web Soil Survey. 3 Jan. 2018. <https://websoilsurvey.sc.egov.usda.gov/ App/WebSoilSurvey.aspx $>$.

Vellidis, G., V. Liakos, C. Perry, M. Tucker, G. Collins, J. Snider, J. Andreis, K. Migliaccio, C. Fraisse, K. Morgan, D. Rowland, and E. Barnes. 2014. A smartphone app for scheduling irrigation on cotton. In S. Boyd, M. Huffman, and B. Robertson (eds.). Proc. 2014 Beltwide Cotton Conf., New Orleans, LA, Nat. Cotton Council, Memphis, TN. 15551.

Zegbe, J.A., M.H. Behboudian, and B.E. Clothier. 2006. Responses of 'petopride' processing tomato to partial root zone drying at different phonological stages. Irrig. Sci. 24:203-210.

Zegbe-Dominguez, J.A., M.H. Behboudian, A. Lang, and B.E. Clothier. 2003. Deficit irrigation and partial root zone drying maintain fruit dry mass and enhance fruit quality in 'Petopride' processing tomato. Scientia Hort. 98:505-510.

Zotarelli, L., M.D. Dukes, G.D. Liu, E.H. Simonne, and S. Agehara. 2016. Principles and practices of irrigation management for vegetable, p. 1119. In: J.H. Freeman, G.E. Vallad, and P.J. Dittmar (eds.). Veg. Prod. Hdbk. for Florida. Univ. of Florida Inst. of Food and Agri. Sci. Gainesville, FL.

Zotarelli, L., J.M. Scholberg, M.D. Dukes, R Munoz-Carpena, and J. Icerman. 2009a. Tomato yield, biomass accumulation, root distribution and irrigation water use efficiency on a sandy soil, as affected by nitrogen rate and irrigation scheduling. Agr. Water Mgt. 96:23-34.

Zotarelli, L., M.D. Dukes, J.M.S. Scholberg, R. Munoz-Carpena, and J. Icerman. 2009b. Tomato nitrogen accumulation and fertilizer use efficiency on a sandy soil, as affected by nitrogen rate and irrigation scheduling. Agr. Water Mgt. 96:1247-1258.

Zotarelli, L., M. Johannes, M. Scholberg, M.D. Dukes, and E. Muñoz-Carpena. 2007. Monitoring of nitrate leaching in sandy soils: Comparison of three methods. J. Environ. Qual. 36:943-962. 